\title{
Professional Responsibility and the Welfare System in Spain at the Turn of the 19th Century
}

\author{
Pilar León Sanz
}

\section{Introduction}

his presentation forms part of a wider study on attitudes of physicians prior to the establishment of a social welfare system in Spain. The research is based on professional sources from the decade immediately prior to, and that immediately following, 1900. More specifically, the sources consist mainly of medical publications of the recently founded Medical Professional Associations, written by 'experts' who considered themselves spokespersons for the medical class.'

1 We are referring to Andrés del Busto y López (1832-1899): professor and chair of various subjects in Madrid, member of the Royal Academy of Medicine (1877); physician in the court of Queen Isabel II. In charge of the professional matters section of the first board of the Colegio de Madrid in 1894. (José Alvarez-Sierra, Diccionario de autoridades médicas (Madrid, 1963), p. 90; Agustín Albarracín Teulón, Historia del Colegio de Médicos de Madrid (Madrid, 2000), p. 19). Eloy Bejarano y Sánchez (1855-1917), first Inspector General of Interior Health of Spain (1904-1910). Academic occupied various political positions (Director of Public Health in 1903) and played an active in association policy. (José Alvarez-Sierra, Diccionario de autoridades médicas (Madrid, 1963), pp. 68-69; Agustín Albarracín Teulón, Historia del Colegio de Médicos de Madrid (Madrid, 2000), pp. 44, 66; Pilar León Sanz, "El poder de los médicos. Un análisis de El ejercicio profesional de la medicina en nuestros días (Madrid, 1906)", Estudos do Século XX, 5 (2005), 223-241). Antonio Piga y Pascual (1879-1952): forensic scientist, professor in the School of Legal Medicine and department head of the center. Academic (1941) and president of the College of Physicians of Madrid (José Alvarez-Sierra, Diccionario de autoridades médicas (Madrid, 1963), p. 110; Agustín Albarracín Teulón, Historia del Colegio de Médicos de Madrid (Madrid, 2000), p. 648). Eduardo Toledo y Toledo, known for his book Sociología médica. Breve estudio de Moral profesional. Madrid 1897, advertised in El Siglo Médico. Angel Pulido Fernández (1852-1932) (Delfín García Guerra, Víctor Álvarez Antuña, "Salud Pública y regeneracionismo en la tarea de Ángel Pulido al frente de la Dirección General de Sanidad”, Dynamis 14 (1994), 23-41; José Alvarez-Sierra, Diccionario de autoridades médicas (Madrid, 1963), p. 113; Agustín Albarracín Teulón, Historia del Colegio de Médicos de Madrid (Madrid, 2000), p. 630). First International 
Before moving forward, it has to be said that the crisis through which the medical profession was passing during this period had a significant impact on the physicians' response to the newly created social welfare systems. Although the need to improve healthcare for the least favoured social classes was considered by physicians as a medical necessity, this did not mean that physicians were willing to give up their right to protect their own interests and prevent other social classes from taking advantage of the new situation. Physicians were responding to a change in the professional model that implied labour dependence with respect to a third party (corporations, private health insurance companies, etc.). They tried to conserve the liberal model of practice and to defend the freedom to establish fees. To this, one needs to add the influence of events taking place in other European countries on Spanish physicians.

\section{Systems of Collectivised Assistance during the Transition from the 19th to the 20th Century}

From the 1880s, the reform and hygiene movements, legislation and socio-economic conditions ignited the desire for change in the social welfare system in Spain. ${ }^{2}$ The systems that evolved were linked to worker collectivism and with movements related to the social doctrine of the Catholic Church, promoted by Pope Leo XIII. ${ }^{3}$ Recognition of the importance of the Catholic movements and of the structures that evolved under the auspices of the Church is unanimous: its

Conference of Professional Medicine and Medical Deontology 1900. And others like Alfredo Fischer Santamaría, José Codina Caltellví, physician of the Academic Hospital and part-time professor, etc. We also reviewed articles which appeared in the professional press such as El Boletin de medicina, cirugía y farmacia. Sociedad Médica Oficial de Socorros Mutuos (1834-1853). And that which resulted from the merger with the medical gazette: El Siglo Médico (1854-1936). It is also necessary to examine the writings of authors such as Severino Aznar Embid (1870-1959), sociologist, politician and journalist Mercedes López Coira, El pensamiento social de Severino Aznar: 1870-1959 (Madrid, 1986); Salustiano del Campo, Historia de la sociología española (Barcelona, 2001). Or Alvaro López Núñez, José Maluquer y Salvador, etc. for their respective role in the creation of the National Welfare Institute.

2 Feliciano Montero García, Los seguros sociales en la España del siglo XX: orígenes y antecedentes de la previsión social (Madrid, 1988); Santiago Castillo, ed., Solidaridad desde abajo: trabajadores y socorros mutuos en la España Contemporánea (Madrid, 1994); Esteban Rodríguez Ocaña, "Los servicios de salud pública en la España contemporánea”, Trabajo social y salud 43 (2002), 91-116; Esteban Rodríguez Ocaña, "La asistencia médica colectiva en España, hasta 1936", in J. Alvarez Junco et al., Historia de la acción social pública en España: Beneficiencia y previsión (Madrid, 1990), pp. 321-361; Rafael Huertas García-Alejo, "Salud Pública en la España contemporánea", Dynamis 14 (1994), 17-21, and the bibliography included therein.

3 José Andrés-Gallego, Pensamiento y acción social de la Iglesia en España (Madrid, 1984), pp. 12-52. Also Feliciano Montero García, El primer catolicismo social y la "Rerum Novarum" en España (Madrid, 1983); Louis Garriguet, La Asociación obrera (Madrid, 1900). 
actions contributed to the maintenance and support of initiatives intended to improve the precarious situation in which a large segment of society found itself. ${ }^{4}$

In the final decade of the 19th century there were, on the one hand, the traditional charitable institutions (general hospitals, homes for the elderly, asylums, orphanages) and others organised at the municipal level. ${ }^{5}$ On the other hand there were sociedades de socorros mutuos (associations of mutual assistance), a system of private, non-profit-making, social welfare institutions, operating in a number of European countries. ${ }^{6}$ The so-called mutualist movement grew uninterruptedly during the second half of the 19th century, with significant growth in the period from 1890 to 1910. In absolute numbers, subscribers and companies reached maximum levels between 1896-1906.

In Spain at this time, there was ongoing socio-political debate about whether the State should intervene in the social welfare systems and about whether social security should be obligatory. In the last decade of the 19th century, the Comision de Reformas Sociales (Commission on Social Reform) proposed the creation of a Caja Nacional de Previsión (National Welfare Fund). ${ }^{8}$ It was not until 1900, however, that public social welfare actually came into being. That was the year the labour accident law was passed.' And in 1908, with the approval of all the political parties after heated debate, the Instituto Nacional de Previsión (National Welfare Institute) was founded. It was severely under-funded, however, and so its functions were limited to other areas:

4 José Andrés-Gallego, Pensamiento y acción social de la Iglesia en España (Madrid, 1984), p. 39; Javier María Pejenaute Goñi, "Las Sociedades de Socorros Mutuos en Navarra (finales del siglo XIX)", in II Congreso Mundial Vasco (San Sebastián, 1987), VI, 273-285; Ángel García-Sanz Marcotegui, Navarra. Conflictividad social a comienzos del s. XX y noticia del anarcosindicalista Gregorio Suberviola Baigorri 1896-1924 (Pamplona, 1984), p. 45, etc.

5 In the 19th century, the charity was regulated by the municipal laws of 1823 and 1836, Decree 1854; Health Law of 1855 and its Regulations of 1868; Municipal Law of 1870; Royal Decree of 1891. Carried forward in the General Health Training Act of 1904.

6 Severino Aznar Embid, El riesgo-enfermedad y las Sociedades de Socorros Mutuos (Madrid, 1914); Alvaro López Núñez, Ideario de previsión social (Madrid, 1943), p. 79; Feliciano Montero García, Los seguros sociales en la España del siglo XX: origenes y antecedentes de la previsión social (Madrid, 1988), p. 97.

7 José Andrés-Gallego, Pensamiento y acción social de la Iglesia en España (Madrid, 1984), pp. 146-150, 408.

8 Feliciano Montero García, Los seguros sociales en la España del siglo XX: orígenes y antecedentes de la previsión social (Madrid, 1988), p. 15.

9 It was followed by others laws: in 1900 the labor of women and children was regulated and in 1904, the law for the protection of minors was approved. Regarding the approval of the Law on Accidents, Feliciano Montero García, Los seguros sociales en la España del siglo XX: orígenes $y$ antecedentes de la previsión social (Madrid, 1988), pp. 121-125. 
Actions relating to the strengthening of the economic, pedagogic and social activities, of both individual and collective nature; vigilance and a higher compensation of risks through reinsurance.

The notion of a subsidiary role for the State prevailed at this time. Private health insurance companies also began offering medical-pharmaceutical services in urban centres. ${ }^{10}$

\section{A Delayed Reaction}

Professional sources, books and magazines, did not examine the relationship between physicians and the associations of mutual assistance until the end of the $19^{\text {th }}$ century, although we have found references to what is happening in other European countries. In 1856, El Siglo médico endorsed the idea that the Sociedades de Socorros Mutuos were frequently "copies of foreign associations" ${ }^{11}$. Two years later, in 1858, it writes about the charity congress held in Frankfurt, where, according to this professional journal, there was discussion about whether charity should be public or private; if it should be organised by town councils or by the state; if it could be secular or lay, religious or organised by individuals. ${ }^{12}$

However, the issue was not debated by professional theorists, such as Bofill, ${ }^{13}$ nor was it included in written works produced by clinicians, such as Letamendi, although he commented extensively on medical fees, the relationship between professionals, responsibility before the law, and the relationship between law and society. References in the medical press were also rare. ${ }^{14}$

It is difficult to explain this apparent lack of interest in the issue, given the large number of publications - we have identified around fifty - on professional topics which appear between 1840 (the year after approval of legislation associated with the associations of mutual assistance) and 1889. There are a number of possible explanations for such an omission: it was not a topic of interest to influential foreign authors who were quoted by Spanish physicians in the first half of the $19^{\text {th }}$ century. It did not appear in the works of Forget ${ }^{15}$, Simon ${ }^{16}$, or Hufeland ${ }^{17}$, one

10 Feliciano Montero García, Los seguros sociales en la España del siglo XX: orígenes y antecedentes de la previsión social (Madrid, 1988), p. 165; Severino Aznar Embid, El riesgoenfermedad y las Sociedades de Socorros Mutuos (Madrid, 1914), p. 20.

11 El Siglo Médico (1856), 398.

12 El Siglo Médico (1858), 31.

13 Simón Bofill y Nonell, Deberes que el médico tiene contraidos con la humanidad (Madrid, 1861).

14 José de Letamendi, Curso de Clínica general ó Canon perpétuo de la practica médica (Madrid, 1894); cf. El Siglo Médico (1897), 373-8; (1898), 22-23 and 54-55; etc.

15 Charles-Polydore Forget, Deberes del médico (Madrid, 1849). 
could also suppose a peaceful and natural collaboration between the physicians and institutions which continued to provide traditional forms of assistance, such as the trades and the guilds. We must keep in mind that those same physicians had their own associations of mutual assistance. ${ }^{18}$ Also, it may be that the numerous and serious problems that the medical profession was experiencing at this time ${ }^{19}$ may have been distracting, perhaps causing it to underestimate the significance of the new institutions being proposed. Moreover, we have already commented supra on the high rise both in the number of bodies and members from the early 1890 s. Together with the traditional Societies and Mutual Protection Societies, new bodies such as mixed (employees and employers) and trade unions appeared.

It should be noted that during the final years of the $19^{\text {th }}$ century meetings were held both inside and outside Spain to discuss social welfare. As a result of these meetings, an ample bibliography was compiled outside Spain. In Spain, a subtle optimism was apparent in the solutions to the urgent professional problems proposed by the consolidation of the professional Councils which facilitated debate and the taking of corporate stances in the medical press. ${ }^{20}$ Most notably, the physicians themselves were those who participated in the establishment of the new welfare systems. This is reflected in the publications and in the events at the end of the $19^{\text {th }}$ and beginning of the $20^{\text {th }}$ century. An excellent example was the organisation in 1900 of the First International Conference of Professional Medicine and Medical Deontology which dedicated the first portion of its agenda to the relationship between the physician and the collectivises, among which were included the mutual insurance companies. ${ }^{21}$ The issue was also included in speeches and papers presented in the newly created medical associations and even in medical school textbooks. The Moureau and Lavrand text of 1901, translated by Sarmiento, in the section on "professional honor", discussed the "involvement of the physician in associations that earn profit" and among the "specific cases", specifically mentioned

16 Maximilien Isidore Amand Simon, Deontología médica. Treinta lecciones sobre los deberes de los médicos en el estado actual de la civilización con un breve resumen de sus derechos (Madrid, 1852) (First edition: Déontologie médicale ou des devoirs et des droits des médecins dans l'état actuel de la civilisation (Paris, 1845). York, 1849).

17 Cristoph Wilhelm Hufeland, Enchiridion medicum: or the practice of medicine (New

18 In El Siglo Médico are gathered the statutes and regulations of some of the medicalpharmaceutical associations published during this period: (1892), 377, 489, 796; (1898), 217. Also, Severino Aznar Embid, El seguro de enfermedad y los médicos (Madrid, 1934).

19 See infra subtitle: A Corporativist Reaction.

20 Agustín Albarracín Teulón, "La profesión médica ante la sociedad española del siglo XIX”, Asclepio 25 (1973), 303-316.

21 The first section of the First International Conference of Professional Medicine and Medical Deontology (1900) was denominated: relationship of the physician with the collectivites. 
"life insurance" and the "associations of mutual assistance" and the "medical reports of the ill". ${ }^{22}$

In 1902 a Labour Accident Congress was held in Bilbao,

which was attended by prestigious national and foreign representatives, [and] gave the public ideas that until then were only held by a limited number of specialists ${ }^{23}$.

Angel Pulido himself, in his speech to the Colegio de Médicos de Madrid in 1903, confirmed the backwardness of Spain and gave details of the systems set up in USA, France, Belgium, Germany and England ${ }^{24}$. And Bejarano admitted "because of the currents of social solidarity which have done miracles in Belgium and in France", organisation was going ahead of "mutual aid associations and trade unions in our country, especially in the large towns"

In Spain, as in the other European countries, the German experience was seen as the background to the argument on the introduction of Social Health policies ${ }^{26}$. However, we must remember that the French model was also of great importance. El Siglo médico simultaneously describes the references from Berlin and Paris. Thus, for example, in 1902, it published the fees of physicians in these two capitals, and news from professional congresses that were held in Germany and France in $1900^{27}$. And in the same year it published: "The New French Health Law and the need for a similar one in Spain"28.

López Piñero pointed out that for many years Spanish $19^{\text {th }}$ century work habitually used the analogical application of foreign studies and statistics, which situation, of which authors were very aware, continued during the first few decades of the $20^{\text {th }}$ century $^{29}$. For example, Severino Aznar complains "the European States are a great distance ahead of us". In fact, he knows and quotes the different statistics for European countries, when the Spanish ones are unknown ${ }^{30}$.

22 Hippolyte Moureau, Hubert Lavrand, El Médico cristiano. Lecciones prácticas de moral médica (Bellín, 1901), pp. 46-50, 120, 123, 124 and 138.

23 Alvaro López Núñez, Ideario de previsión social (Madrid, 1943), pp. 96 and 101. (Conference of 1920).

24 Ángel Pulido Fernández, Relación de las clases médicas (con las asociaciones cooperativas e industriales benéfico-sanitarias) (Madrid, 1903), pp. 14-16.

25 Eloy Bejarano y Sánchez, Discursos leidos ante la Real Academia de Medicina. (Madrid, 1906), p. 72.

26 Feliciano Montero García, Los seguros sociales en la España del siglo XX: orígenes y antecedentes de la previsión social (Madrid, 1988), p. 43.

27 El Siglo médico (1902), 402-408.

28 El Siglo médico (1902), 758-759.

29 Jose María López Piñero, Luis García Ballester, Pilar Faus Sevilla, Medicina y sociedad en la España del siglo XIX (Madrid, 1964); Esteban Rodríguez Ocaña, La constitución de la medicina social como disciplina en España (1882-1923) (Madrid, 1988), p. 17.

30 Severino Aznar Embid, El riesgo-enfermedad y las Sociedades de Socorros Mutuos (Madrid, 1914), p. 31. 


\section{A Corporativist Reaction}

The unease felt in the medical community due to its low standing in society, a reflection of the troubled period through which the profession passed in the $19^{\text {th }}$ century, continued unabated. ${ }^{31}$ This was somewhat difficult to explain, given the scientific advances of that time. At the heart of the situation were various professional factors. There continued to persist the question of the various types of professionals: physicians, surgeons, physician-surgeons, of the first, second or third class. ${ }^{32}$ The similarity between the qualifications resulted in an increase in the number of physicians, to which was added the increase in medical school enrollment. ${ }^{33}$ And with it

the inexorable law of supply and demand that also governs the financial destiny of our profession (...) fuelled scorn for the profession and brought severe disorder to the economic state of the physicians. ${ }^{34}$

Bejarano accurately noted: "The medical crisis demonstrates three distinct facets: the scientific, the social and the economic." ${ }^{35}$

From the corporate perspective, the call to collectivise was constant. Only in this manner would a solution be found to such a critical situation. ${ }^{36}$ The physicians' mistake was in not joining together to defend their mutual interests. "Our error was in not knowing how to counteract the effects produced by the few effective measures taken against us." ${ }^{{ }^{37}}$ This perception strengthened the tendency towards professional associations which had begun to take hold:

31 Agustín Albarracín Teulón, "La profesión médica ante la sociedad española del siglo XIX”, Asclepio 25 (1973), 303-316 (308); Anne Digby, The evolution of British general practice 1850-1948 (Oxford, 1999), pp. 23-25, 111; Jacques Léonard, La vie quotidienne du médecin de province au XIXe siècle (Paris, 1977); José Valenzuela Candelario, "El espejismo del ejercicio libre. La ordenación de la asistencia médica en la España decimonónica”, Dynamis, 114 (1994), 269304; Francisco Villacorta Baños, Profesionales y burócratas: Estado y poder corporativo en la España del siglo XX 1890-1923 (Madrid, 1989).

32 Agustín Albarracín Teulón, "La asistencia médica rural en la España del siglo XIX", Asclepio 25 (1969), 35-42; Agustín Albarracín Teulón, "La titulación médica rural en la España del siglo XIX", Asclepio 21 (1969), 27-34.

33 Agustín Albarracín Teulón, "La titulación médica en España durante el siglo XIX", Cuadernos de Historia de la Medicina Española XII (1973), 15-80.

34 Eloy Bejarano y Sánchez, Discursos leidos ante la Real Academia de Medicina. (Madrid, 1906), p. 64.

35 Eloy Bejarano y Sánchez, Discursos leidos ante la Real Academia de Medicina. (Madrid, 1906), p. 15.

36 Eloy Bejarano y Sánchez, Discursos leidos ante la Real Academia de Medicina. (Madrid, 1906), p. 15.

37 Eduardo Toledo y Toledo, Sociología médica. Breve estudio de Moral profesional (Madrid, 1897), p. 99; also the same idea in Ángel Pulido Fernández, Discurso exponiendo el 
We physicians have much to learn, in this sense, from any workers' collective: the stonecutters and the carpenters join together in a union to dignify their art and to counter attempts to denigrate their labor at any cost. ${ }^{38}$

This resulted in a period of development of professional self-regulation, of corporate protest in support of the recently achieved medical autonomy. There were few alternatives proposed in response to the new collectivised social welfare systems. Only Ángel Pulido, pointed out, in both 1902 and 1907, the harmful effects that such systems had had in other countries, such as Belgium and France, such as the lack of respect for the individual, for which he enunciated the slogan "united, but not by force". He attempted to assimilate the dissident voices, complaining about the limitation imposed on the freedom of practice by part of the profession. ${ }^{39}$

\section{Attitude of the Physicians to the Different Welfare Systems}

Criticism of insurance companies was unanimous. The negative image was due to the corporation's focus on profit and these corporations were often compared with businesses that buy and sell, leaving families, the ill and medical professionals vulnerable. This was the view of Eduardo Toledo y Toledo ${ }^{40}$, Antonio Piga ${ }^{41}$, Eloy Bejarano ${ }^{42}$ and Ángel Pulido. ${ }^{43}$ They called for the medical community to unite and to resist the development and implantation of the corporate model. This will be further discussed later.

programa económico y profesional del Colegio en la Junta celebrada el día 27 de octubre de 1907 (Madrid, 1907), p. 20.

38 Eloy Bejarano y Sánchez, Discursos leidos ante la Real Academia de Medicina. (Madrid, 1906), p. 73.

39 In El Siglo Médico (1902), 379; Ángel Pulido Fernández, Relación de las clases médicas (con las asociaciones cooperativas e industriales benéfico-sanitarias) (Madrid, 1903); Ángel Pulido Fernández, Discurso exponiendo el programa económico y profesional del Colegio en la Junta celebrada el día 27 de octubre de 1907 (Madrid, 1907). Cf. Agustín Albarracín Teulón, "Asociaciones médicas del siglo XIX", Cuadernos de Historia de la Medicina Española X (1971), 119-186 (180183).

40 Eduardo Toledo y Toledo, Sociología médica. Breve estudio de Moral profesional (Madrid, 1897), p. 19.

41 Antonio Piga y Pascual, La Moral Médica y la "Fundación Sta. Cándida" (Madrid, 1907), p. 5.

42 Eloy Bejarano y Sánchez, Discursos leidos ante la Real Academia de Medicina. (Madrid, 1906), p. 35.

43 Ángel Pulido Fernández, Discurso exponiendo el programa económico y profesional del Colegio en la Junta celebrada el día 27 de octubre de 1907 (Madrid, 1907), p. 20. 
As to mutual societies and the associations of mutual assistance, there was a variety of opinions. While Eloy Bejarano criticised them, ${ }^{44}$ Ángel Pulido applauded them as long as they were not for profit. ${ }^{45}$ Above all, the three general principles defended by the latter in 1903 were the following:

1. the principle of the right of the patient to medical assistance; 2. the right of the physician to practice; 3 . the mediation between corporations. ${ }^{46}$

The resonance of these ideas in later documents - even those of today - was because they were based on a concept of rights and duties and participation of the physicians in the coordination of the systems. However, the context and significance was quite different since the right to practice referred not only to the physician's duty to society and its institutions but also to his relationship with other professionals. ${ }^{47}$

Yet, in practice, collaboration existed between the physicians and the associations of mutual assistance. Take, for example, the participation of physicians in the Sociedad de Socorros Mutuos Centro Escolar y Dominical de Obreros de Pamplona which, beginning in 1881, became involved in welfare, education, and prevention activities. ${ }^{48}$ This was in response to the concern of the physicians for society and the environment: the issues of hygiene and sanitation were very important at the time. ${ }^{49}$

\section{Professional Responsibility}

The professional arguments used against the associations, mutuals and insurance companies were formulated around, in addition to the professional instability of the times, the changes in civil and criminal responsibility of the physician as a result of

44 Eloy Bejarano y Sánchez, Discursos leidos ante la Real Academia de Medicina. (Madrid, 1906), p. 72.

45 Ángel Pulido Fernández, Discurso exponiendo el programa económico y profesional del Colegio en la Junta celebrada el día 27 de octubre de 1907 (Madrid, 1907), p. 30.

46 Ángel Pulido Fernández, Relación de las clases médicas (con las asociaciones cooperativas e industriales benéfico-sanitarias) (Madrid, 1903), p. 10.

47 Mercedes Samaniego Boneu, Los seguros sociales en la España del siglo XX: la unificación de los seguros sociales a debate: la Segunda República (Madrid, 1988). Y Esteban Rodríguez Ocaña, "La asistencia médica colectiva en España, hasta 1936"; in J. Alvarez Junco et al., Historia de la acción social pública en España: Beneficiencia y previsión (Madrid, 1990), pp. 346-7.

48 Sagrario Anaut Bravo, Luces y sombras de una ciudad: los límites del reformismo social y del higienismo en Pamplona (Pamplona, 2001), p. 248.

49 Henri Hatzfeld, Du Paupérisme à la Sécurité Sociale: essai sur les origines de la sécurité sociale en France, 1850-1940 (Paris, 1971). 
new legal regulations. ${ }^{50}$ The physicians were sensitive to, and anxious about, maintaining their independence and autonomy which they felt were being threatened.

\section{a) An Intermediary in the Doctor-Patient Relationship}

The physicians cautioned that the intervention of a company, corporation or mutual association in clinical practice would have a negative impact on the doctorpatient relationship due to the involvement of interests alien to the administration of medical assistance:

The physician, as individual and professional under such conditions, could not treat patients as individuals but rather would be obliged to treat the ill of institutions and vast collectives, disciplined and powerful, prepared to defend their interests and objectives. $^{51}$

The physician would have to justify his work to third parties and obligatorily confer that which before he previously offered out of virtue; thereby exercising restrictions on the delivery and generosity of patient care which had until now been proverbial..$^{52}$ The result would be, as Pulido stated in 1903, a distancing of doctor and patient. ${ }^{53}$ It should be noted that the author seemed to allude more to the status and professional independence of the physician than to the needs of the infirm in so far as any threat to confidence as a result of changes to the doctor-patient relationship was concerned..$^{54}$

50 Changes came about in a good number of European countries. In Spain in 1822 appeared the Penal Code (revised in 1848, 1870 and 1928), in 1829 the Commercial Code (modified in 1885), in 1859 the Civil Code (revised in 1889). There were numerous commentaries in this area in the medical journals during the second half of the 19th century. Cf. Juan José Llovet, "Problemática e ideologías de la responsabilidad médica en España (18501949)", Asclepio 44 (1992), 71-94.

51 Ángel Pulido Fernández, Discurso exponiendo el programa económico y profesional del Colegio en la Junta celebrada el día 27 de octubre de 1907 (Madrid, 1907), p. 9.

52 Ángel Pulido Fernández, Relación de las clases médicas (con las asociaciones cooperativas e industriales benéfico-sanitarias) (Madrid, 1903), p. 10; Ángel Pulido Fernández, Discurso exponiendo el programa económico y profesional del Colegio en la Junta celebrada el día 27 de octubre de 1907 (Madrid, 1907), p. 30.

53 Ángel Pulido Fernández, Relación de las clases médicas (con las asociaciones cooperativas e industriales benéfico-sanitarias) (Madrid, 1903), p. 10.

54 Ángel Pulido Fernández, Discurso exponiendo el programa económico y profesional del Colegio en la Junta celebrada el día 27 de octubre de 1907 (Madrid, 1907), p. 22. 


\section{b) Freedom to Practice}

The freedom to practice medicine was a constant demand. Toledo called for it in $1897,{ }^{55}$ Bejarano in $1906,{ }^{56}$ and Pulido in $1907,{ }^{57}$ among many others. All were opposed to physician activities being overseen by persons outside the profession, although they recognised the duty to continue medical attention once initiated:

The free physician has the perfect right to deny certain assistance if he or she so decides, but once accepted, such assistance should continue until no longer necessary. ${ }^{58}$

They reinforced the argument by stating that the right of election similarly existed for the patient:

Is it proper to assign a particular physician to a patient, when to a physician the patient must submit his life, secrets, powers, all that which he holds dear? Is it proper to impose on him a physician who is not to his liking?"

The Union of Physicians of Girona focused on this issue:

In the ideal situation, the patient's freedom should be respected, allowing him to choose from among those physicians in the community willing to provide that service. $^{60}$

It is interesting to note that by calling for a patient's liberty to choose a physician, the physicians are displacing, at least partially, the responsibility for the medical act towards the patients and their families. ${ }^{61}$

55 Eduardo Toledo y Toledo, Sociología médica. Breve estudio de Moral profesional (Madrid, 1897), p. 54.

56 Eloy Bejarano y Sánchez, Discursos leídos ante la Real Academia de Medicina. (Madrid, 1906), p. 72.

57 Ángel Pulido Fernández, Discurso exponiendo el programa económico y profesional del Colegio en la Junta celebrada el día 27 de octubre de 1907 (Madrid, 1907), p. 25.

58 Eduardo Toledo y Toledo, Sociología médica. Breve estudio de Moral profesional (Madrid, 1897), p. 223.

59 Ángel Pulido Fernández, Discurso exponiendo el programa económico y profesional del Colegio en la Junta celebrada el día 27 de octubre de 1907 (Madrid, 1907), p. 27.

60 Association des Médicins de La Gironde, Consejos profesionales y principios de Deontología médica (Girona, 1898), p. 30. This recommendations were assumed by the Medical Union of the province of Girona.

61 Ángel Pulido Fernández, Discurso exponiendo el programa económico y profesional del Colegio en la Junta celebrada el día 27 de octubre de 1907 (Madrid, 1907), p. 28. 


\section{c) Professional Secrecy and Truthfulness, and the Insurance Companies}

The sanctity of the doctor-patient relationship was often a burning issue during this period $^{62}$ and it appeared once again threatened by the interference of the mutuals and insurance companies. The medical profession's reaction was predictable: the Physician's Union of Girona imposed on its members the obligation to maintain professional secrecy with warnings similar to those existing today. ${ }^{63}$ Dr. Bejarano was also strict in this respect. ${ }^{64}$ Nevertheless, the relationship between the physicians and the companies also had to be a loyal and truthful one. Protection of the insured patient would not justify acts against insurance company interests:

Whoever accepts the position as insurance company doctor becomes an extension of same and is obliged to provide the truth whenever demanded. ${ }^{65}$

The lines of conflict were drawn since doctors could not respect the requirements of the associations or corporations and those of the insured patients simultaneously. ${ }^{66}$

The medical reports caused many complications. They required constant, indepth training in wider areas but the worst thing was that some physicians would have to supervise and demand compliance from other physicians, since their function was to "watch over the treatment in the hospitals, infirmaries or in the private home." ${ }^{37}$ This was, in the opinion of Bejarano, yet another example of interference by the State into areas which were exclusively medical in nature, prompted by "the currents of social solidarity and charity" ${ }^{68}$

62 In Spain - as well as in other European countries - doubts arose about the new laws and civil codes which obligated professionals to testify as experts before companies and judges. In Spain, this was the professional issue most often addressed in doctoral theses and speeches in the second half of the 19th century.

63 Association des Médicins de La Gironde, Consejos profesionales y principios de Deontología médica (Girona, 1898), p. 31.

64 Eloy Bejarano y Sánchez, Discursos leidos ante la Real Academia de Medicina. (Madrid, 1906), pp. 35 and 42.

65 Association des Médicins de La Gironde, Consejos profesionales y principios de Deontología médica (Girona, 1898), p. 31.

66 Antonio Martín y Menéndez, Apuntes médico-legales referentes al secreto profesional en España (Madrid, 1900), pp. 14-16.

67 Eloy Bejarano y Sánchez, Discursos leidos ante la Real Academia de Medicina. (Madrid, 1906), p. 75.

68 Eloy Bejarano y Sánchez, Discursos leidos ante la Real Academia de Medicina. (Madrid, 1906), p. 74. 


\section{Conclusion: In Favor of a Good and Necessary Social Welfare System?}

We found physicians in favour of establishing a welfare system that was not exclusively public which, in addition to benefiting the needy, would benefit the interests of the profession as well. To that end, they proposed reinforcing systems which offered assistance to the greatest number of needy, which in turn would most benefit them.

Properly understood, mutualism represents nothing more than the effort by the lowest social classes to be integrated into society. That is, these social classes try to free themselves from State charity, so if all those classes remove themselves from State charity, they can again form part of the doctors' clientele. ${ }^{69}$

We can conclude by stating that during the last decade of the $19^{\text {th }}$ century and the first of the 20th, there began a debate regarding the systems of collectivized health care in Spain. It may have been triggered by the State's initiative toward greater intervention and its moving ahead with legislative measures, in addition to the proliferation of private insurance companies. The issue discussed by the physicians had to do with their professional identity - the fear of changing from free professionals into professionals contracted or paid by third parties. The professional association and its obligatory nature justified the promising tone of the debate, based on the strength provided by the cohesiveness of the physicians. We discovered intransigent and theoretical postures regarding the limitation of the freedom to practice that, over time, would become further radicalised, ${ }^{70}$ balanced against a pragmatic collaborationism, extremely conventional in its attention to those most in need.

The awareness of change is perceived in this attitude, a change toward a greater role of the State and towards the obligatory nature of the welfare systems which the physicians could easily observe in other countries. ${ }^{71}$

Pilar León Sanz is Professor of History of Medicine at the Department of Biomedical Humanities, School of Medicine, University of Navarra. Pamplona 31008 Spain.

69 Ángel Pulido Fernández, Discurso exponiendo el programa económico y profesional del Colegio en la Junta celebrada el día 27 de octubre de 1907 (Madrid, 1907), p. 25.

70 Esteban Rodríguez Ocaña, "La asistencia médica colectiva en España, hasta 1936"; in J. Alvarez Junco et al., Historia de la acción social pública en España: Beneficiencia y previsión (Madrid, 1990), pp. 353-355.

71. Ángel Pulido Fernández, Discurso exponiendo el programa económico y profesional del Colegio en la Junta celebrada el día 27 de octubre de 1907 (Madrid, 1907), p. 27. 


\section{References}

Albarracín Teulón, Agustín, "La titulación médica rural en la España del siglo XIX," Asclepio 21 (1969), 27-34.

Albarracín Teulón, Agustín, "La asistencia médica rural en la España del siglo XIX," Asclepio 25 (1969), 35-42.

Albarracín Teulón, Agustín, Asociaciones médicas del siglo XIX," Cuadernos de Historia de la Medicina Española X (1971), 119-186.

Albarracín Teulón, Agustín, "La profesión médica ante la sociedad española del siglo XIX," Asclepio 25 (1973), 303-316.

Albarracín Teulón, Agustín, "La titulación médica en España durante el siglo XIX," Cuadernos de Historia de la Medicina Española XII (1973), 15-80.

Albarracín Teulón, Agustín, Historia del Colegio de Médicos de Madrid. Madrid, 2000.

Alvarez-Sierra, José, Diccionario de autoridades médicas. Madrid, 1963.

Anaut Bravo, Sagrario, Luces y sombras de una ciudad: los limites del reformismo social $y$ del higienismo en Pamplona, Pamplona, 2001.

Andrés-Gallego, José, Pensamiento y acción social de la Iglesia en España. Madrid, 1984.

Association des Médicins de La Gironde, Consejos profesionales y principios de Deontología médica. Girona, 1898.

Aznar Embid, Severino, El riesgo-enfermedad y las Sociedades de Socorros Mutuos. Madrid, 1914.

Aznar Embid, Severino, El seguro de enfermedad y los médicos. Madrid, 1934.

Bejarano y Sánchez, Eloy, Discursos leidos ante la Real Academia de Medicina en la recepción pública del ... Madrid, 1906.

Bofill y Nonell, Simón, Deberes que el médico tiene contraidos con la humanidad, Madrid, 1861.

Bynum, William F, "Médecine et société, pp. 295-317 in Grmek, Mirko Drazen, ed., Histoire de la pensée medicale en occident, Paris 1998.

Campo, Salustiano del, Historia de la sociología española. Barcelona, 2001.

Codina Castellví, José, La futura revolución en el ejercicio práctico de la medicina. Madrid, 1904.

Digby, Anne, The evolution of British general practice 1850-1948. Oxford, 1999.

El Boletin de medicina, cirugía y farmacia. Sociedad Médica Oficial de Socorros Mutuos. Madrid, 1834-1853.

El Siglo Médico. Madrid, 1854-1936.

Forget, Charles-Polydore, Deberes del médico. Madrid, 1849.

García Guerra, Delfín, Álvarez Antuña, Víctor, "Salud Pública y regeneracionismo 
en la tarea de Ángel Pulido al frente de la Dirección General de Sanidad," Dynamis 14 (1994), 23-41.

García-Sanz Marcotegui, Ángel, Navarra. Conflictividad social a comienzos del s. XX y noticia del anarcosindicalista Gregorio Suberviola Baigorri (1896-1924). Pamplona, 1984.

Garriguet, Louis, La Asociación obrera. Madrid, 1900.

Hatzfeld, Henri, Du Paupérisme à la Sécurité Sociale: essai sur les origines de la sécurité sociale en France, 1850-1940. Paris, 1971.

Huertas García-Alejo, Rafael, "Salud Pública en la España contemporánea," Dynamis 14 (1994), 17-21.

Hufeland, Cristoph Wilhelm, Enchiridion medicum: or the practice of medicine, 3th ed., New York, 1849.

León Sanz, Pilar, "El poder de los médicos. Un análisis de El ejercicio profesional de la medicina en nuestros días (Madrid, 1906)," Estudos do Século XX, 5 (2005), 223-241.

Léonard, Jacques Léonard, La vie quotidienne du médecin de province au XIXe siècle. Paris, 1977.

Letamendi, José de, Curso de Clínica general ó Canon perpétuo de la practica médica. Madrid, 1894.

Llovet, Juan José, "Problemática e ideologías de la responsabilidad médica en España (1850-1949)," Asclepio 44 (1992), 71-94.

López Coira, Mercedes, El pensamiento social de Severino Aznar (1870-1959). Madrid, 1986.

López Núñez, Alvaro, Ideario de previsión social. Madrid, 1943.

López Piñero, José María, García Ballester, Luis, Faus Sevilla, Pilar, Medicina y sociedad en la España del siglo XIX, Madrid, 1964.

Martín y Menéndez, Antonio, Apuntes médico-legales referentes al secreto profesional en España, Madrid, 1900.

Montero García, Feliciano, El primer catolicismo social y la "Rerum Novarum" en España, Madrid, 1983.

Montero García, Feliciano, Los seguros sociales en la España del siglo XX: origenes y antecedentes de la previsión social, Madrid, 1988.

Moureau, Hippolyte, Lavrand, Hubert, El Médico cristiano. Lecciones prácticas de moral médica. Montdidier, 1901.

Pejenaute Goñi, Javier María, "Las Sociedades de Socorros Mutuos en Navarra (finales del siglo XIX)" volume VI, 273-285 in II Congreso Mundial Vasco, San Sebastián, 1987.

Piga y Pascual, Antonio, La Moral Médica y la "Fundación Sta. Cándida", Conferencia, Madrid, 1907.

Primer Congreso internacional de Medicina profesional y deontología médica 1900, Gerona, 1899. 
Pulido Fernández, Ángel, Relación de las clases médicas (con las asociaciones cooperativas e industriales benéfico-sanitarias). Madrid, 1903.

Pulido Fernández, Ángel, Discurso del Presidente Excmo. Sr. D. ... exponiendo el programa económico y profesional del Colegio en la Junta celebrada el día 27 de octubre de 1907. Madrid, 1907.

Rodríguez Ocaña, Esteban, La constitución de la medicina social como disciplina en España (1882-1923). Madrid, 1988.

Rodríguez Ocaña, Esteban, "La asistencia médica colectiva en España, hasta 1936," pp. 321-361 in José Alvarez Junco, ed., Historia de la acción social pública en España: Beneficiencia y previsión, Madrid, 1990.

Rodríguez Ocaña, Esteban, "Los servicios de salud pública en la España contemporánea," Trabajo social y salud 43 (2002), 91-116.

Samaniego Boneu, Mercedes, Los seguros sociales en la España del siglo XX: la unificación de los seguros sociales a debate: la Segunda República. Madrid, 1988.

Simon, Maximilien Isidore Amand, Déontologie médicale ou des devoirs et des droits des médecins dans l'état actuel de la civilisation, Paris, 1845. (First Spanish edition. Tr. Francisco Ramos y Borguella. Madrid, 1852).

Toledo y Toledo, Eduardo, Sociología médica. Breve estudio de Moral profesional. Madrid, 1897.

Valenzuela Candelario, José, "El espejismo del ejercicio libre. La ordenación de la asistencia médica en la España decimonónica," in Dynamis 114 (1994), 269304.

Villacorta Baños, Francisco, Profesionales y burócratas: Estado y poder corporativo en la España del siglo XX 1890-1923. Madrid, 1989. 